University of Colorado Law School

Colorado Law Scholarly Commons

Books, Reports, and Studies

Getches-Wilkinson Center for Natural

Resources, Energy, and the Environment

1992

\title{
America's Waters: A New Era of Sustainability: Report of the Long's Peak Working Group on National Water Policy
}

David H. Getches

Lawrence J. MacDonnell

Charles F. Wilkinson

Long's Peak Working Group on National Water Policy

University of Colorado Boulder. Natural Resources Law Center

Follow this and additional works at: https://scholar.law.colorado.edu/books_reports_studies

Part of the Water Resource Management Commons

\section{Citation Information}

America's Waters: A New Era of Sustainability: Report of the Long's Peak Working Group on National Water Policy: Objectives and Initiatives (Natural Res. Law Ctr., Univ. of Colo. Sch. of Law 1992). 


\section{William A. Wise Law Library
Colorado \\ UNIVERSITY OF COLORADO BOULDER

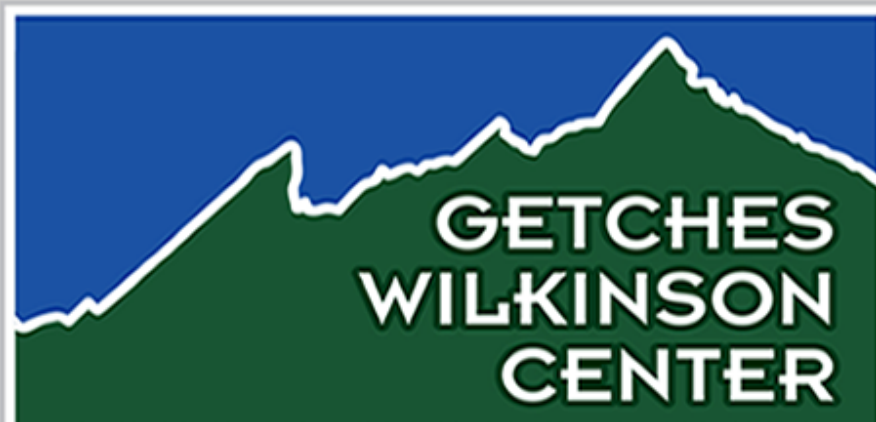 \\ FOR NATURAL RESOURCES, ENERGY, AND THE ENVIRONMENT \\ Getches-Wilkinson Center Collection}

AMERICA's WATERS: A NeW ERA OF SUSTAINABILITY: RePORT OF tHe LONG'S PEAK Working GROUP on National Water Policy: ObJeCtIVES AND INITIATIVES (Natural Res. Law Ctr., Univ. of Colo. Sch. of Law 1992).

Reproduced with permission of the Getches-Wilkinson Center for Natural Resources, Energy, and the Environment (formerly the Natural Resources Law Center) at the University of Colorado Law School. 


\section{AMERICA'S WATERS:}

\section{A NEW ERA OF SUSTAINABILITY}

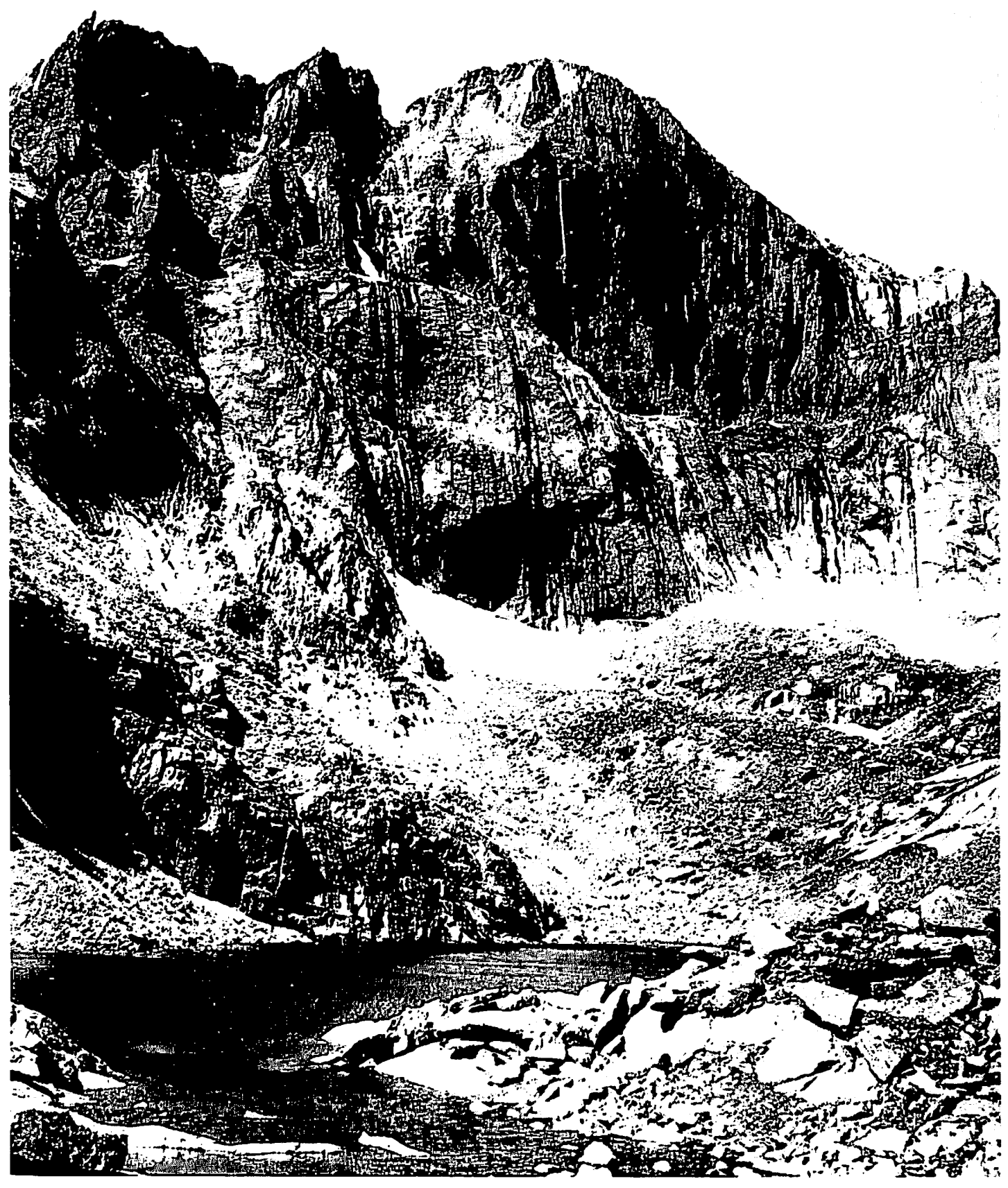

REPORT OF THE LONG'S PEAK WORKING GROUP

on National Water Policy

Objectives and Initiatives

December 1992 


\title{
AMERICA'S WATERS: A NEW ERA OF SUSTAINABILITY
}

\author{
Report of the Long's Peak \\ Working Group on \\ National Water Policy
}

\section{TABLE OF CONTENTS}

2 Preface

3 Introduction and Overview

4 National Policy Objectives

8 Institutional Reform

9 Recommendations

9

First 100 Days

10 Mid-Term Recommendations

\section{The Natural Resources Law Center December 1992}




\section{PREFACE}

The Natural Resources Law Center of the University of Colorado convened a working group of 30 national experts in water policy at Allenspark, Colorado, near Longs Peak on December 6-8, 1992. The Keystone Center facilitated the meeting. During the meeting, we attempted to focus our collective expertise on the critical water policy issues and opportunities for action by the Clinton-Gore Administration.

This statement is not intended to be exhaustive. Rather, we hope that it will be useful to the new Administration, at an historic moment, in charting national objectives and suggesting specific decisions for developing a new approach toward managing America's waters.

The participants in the Longs Peak meeting attended as individuals, not as formal representatives of their agencies or organizations. The report as a whole is strongly and unanimously endorsed by the participants named below, but may not necessarily reflect the views of their employers.

Sarah F. Bates, Natural Resources Law Center

Michael Blumm, Lewis and Clark Northwestem School of Law

Jo Clark, Western Governors' Association

Dana Sebren Cooper, Committee on Energy and Natural Resources, U.S. Senate

Dennis Donald, The Nature Conservancy

Bruce Driver, Attorney and Consultant

John E. Echohawk, Native American Rights Fund

Jeffrey P. Featherstone, Delaware River Basin Commission

Karen Garrison, Natural Resources Defense Council

David H. Getches, University of Colorado School of Law

Don Gray, Environmental and Energy Study Institute

Frank Gregg, University of Arizona, School of Renewable Natural Resources

Tom Jensen, Grand Canyon Trust

Steve Lanich, Committee on Interior and Insular Affairs, U.S. House of Representatives

David Lester, Council on Energy and Resources Tribes
Lawrence J. MacDonnell, Natural Resources Law Center

Guy Martin, Perkins Coie

Jerome C. Muys, Will and Muys

Ed Osann, National Wildlife Federation

Ed Pembleton, National Audubon Society

Dale Pontius, American Rivers

Jim Posewitz, Montana Fish, Wildlife and Parks

Teresa A. Rice, Natural Resources Law Center

Peter Rogers, Harvard University

Donald Snow, Northem Lights Research and Education Institute

John E. Thorson

Jim Tripp, Environmental Defense Fund

John Volkman, Northwest Power Planning Council

Charles F. Wilkinson, University of Colorado School of Law

David Yardas, Environmental Defense Fund 


\section{INTRODUCTION AND OVERVIEW}

Sound water policy must address the contemporary and long-term needs of humans as part of the ecological community. Nationally, we have not been using water in a manner that meets these needs on a sustainable basis. Examples include the endangered Columbia River salmon, the overtaxed San Francisco Bay Delta, the poisoned Kesterson National Wildlife Refuge, the salt-choked Colorado River, the vanishing Ogalalla Aquifer, Louisiana's eroding Delta, New York's precarious Delaware River water supply, and the dying Florida Everglades. The environmental costs of current water policy are extraordinary, both to this and future generations.

In America's past, water seemed abundant and nature forgiving. Federal funding was plentiful, and extensive subsidies for development encouraged inefficient use of water. Single interest water policies did not balance the diversity of human and natural needs in water. Intensive economic uses - agriculture, hydropower, flood control, navigation, and urban development - became the dominant forces in managing water. All too often, other concems including sound fiscal policy and the needs of Indian tribes, other ethnic communities, and ecosystems - were ignored. Federally financed water projects were built to control most of the nation's surface water. These initiatives have accomplished considerable societal benefits but have resulted in enormous expenditures and elaborate programs with inherent contradictions, inefficiencies, and a lack of coordination.
The era of building major projects has passed. Neither the economy nor the environment can tolerate more such projects. It is time to reorient the federal role to satisfy new needs consistent with a policy of sustainability.

A major movement toward water policy reform already is afoot at the local, state, tribal, regional, and federal levels. Some examples of these innovations include state and federal programs for instream flow protection, pollution prevention, recognition of the public interest, development of watershed and regional water management approaches, and comprehensive settlements of tribal reserved water rights. The Clinton Administration should build upon this momentum, fulfilling Aldo Leopold's "Land Ethic" by taking firm and responsible action to help create a visionary approach toward America's waters.

A national water policy based on sustainability must include a thorough re-examination of federal policies affecting water quality and aquatic systems consistent with social equity, economic efficiency, ecological integrity, and continued commitment to federal trust responsibilities to tribes. Implementation of a truly national, not "federal," water policy requires the federal government to facilitate, support, and help coordinate efforts to optimize the effectiveness of all levels of government - federal, state, tribal, and local. 


\section{NATIONAL POLICY OBJECTIVES}

A national water policy should reform water governance to achieve four objectives for sustainable water use: water use efficiency and conservation, ecological integrity and restoration, clean water, and equity and participation in decisionmaking. Institutional reform to advance these objectives must be sensitive to human economic needs and the government's financial constraints.

\section{WATER USE EFFICIENCY AND CONSERVATION}

Water is used inefficiently all across the United States, whether in agriculture (the largest single user of America's waters), in industry, or in urban areas. Government has played an active role in building water projects but has taken a passive approach toward encouraging water conservation. Despite water's importance as a public resource, state and federal governments have treated it as a free good, allowing the appropriation of water from rivers, aquifers, and lakes without charge. Water is made available to customers at prices far below its actual value, even when it was developed, stored, and transported at great cost.

Changing economic, social, and environmental values and emerging new technology have made water conservation one of the most promising strategies for protecting existing water supplies, maintaining water quality and ecosystems, sustaining instream flows, resolving long-standing water conflicts (including Indian water rights), and establishing a sustainable water program. There is broad public support for achieving efficiency in urban and agricultural water use. Methods include water conservation, water saving technology, pricing reforms, and reallocation from lower to higher priority uses. Although efficient water use produces economic, social, and environmental benefits, improved efficiency often is viewed as beyond the traditional responsibilities of water and wastewater agencies. To promote greater water use efficiency, the federal govemment should encourage more widespread use of integrated resource planning and management by water and wastewater agencies and require it as a condition of financial assistance.

\section{General Principles}

- Increased demand on water resources, rising costs for water treatment, and contemporary environmental values combine to make the efficient use of water resources a central aspect of all water policy.

- The federal government should provide leadership, making water conservation an explicit part of every water program and policy.

- Transfers of water from one use to another can contribute substantially to water use efficiency, and should be facilitated by the federal government, taking into account environmental and equity considerations.

- The efficient use and conservation of water will be optimized through cooperation among federal, state, local, and tribal governments, and by an open participatory process. 


\section{General Principles}

- Watersheds should form the basic unit of analysis and activity in order to protect and sustain aquatic biological diversity, including instream, wetland, riparian, and related upland resources. Watershed restoration priorities should, however, reflect the role and importance of these resources as components of larger regional, interstate, or even international ecosystems.

- Preventive strategies and integrated responses should replace crisis-oriented management, which has typified our response to the threat of species loss.

- Continued improvements in information should be sought, but data limitations cannot justify lack of action. Policy should be based upon "adaptive management," the principle that environmental restoration programs may be designed as experiments to resolve pressing questions where there are major unknowns; flexible programs are based on the best available information and experience and may be amended as new information becomes available.

- Restoration activities should be structured and implemented at the local, regional, state, and tribal levels to secure the long-term health and viability of local communities and to re-establish links between community-scale economics and ecology.

\section{ECOLOGICAL INTEGRITY AND RESTORATION}

Our nation's rivers, lakes and wetlands have been the source of many human benefits. However, it is increasingly apparent that these benefits come at the expense of the country's natural capital. We have experienced declines in water quality, biological diversity, and the viability of aquatic ecosystems as a result of intensive water development and use.

The rationale for the protection of ecological systems and processes is in part based on human self interest. Yet it is ecosystem health that ultimately translates into community and economic sustainability. Ecological integrity thus is essential to economic sustainability. In addition, it reflects our ethical need to preserve natural areas upon which so many living things depend. Thus, ecological protection assumes a priority beyond the measure of economic analysis.

Agency mandates frequently are weak, ineffective and conflicting. No single agency serves as the necessary focal point for ecosystem protection needs in ongoing water management decisions. 


\section{CLEAN WATER}

A central objective of the Clean Water Act - to restore and maintain the chemical, physical and biological integrity of the nation's waters - remains unfulfilled. Clean water is essential to the health and well being of people and ecosystems. It is necessary for economic security and sustainability. Despite some progress, many obstacles stand in the way of maintaining high quality water. Serious remaining problems include: poorly controlled polluted nunoff (nonpoint source discharges) - which accounts for half of national pollution loads; failure to integrate land and water management; fragmented regulatory responsibility; inadequate water quality standards and lax enforcement; and inadequate attention to ecosystem protection.

\section{EQUITY AND PARTICIPATION IN DECISIONMAKING}

Federal and state water policy often has exacted extraordinary social costs. Indian tribes have been prevented from receiving the benefits of federal water development in spite of promises made in treaties and the trust obligation of the United States. Traditional Hispanic communities have seen their acequias and traditional pattems of water management and use overwhelmed by state and federal water laws and policies. Millions of people in the South have seen fishing and hunting habitat vanish as wetlands have disappeared. Numerous rural communities, especially in the West, have had their water supplies transported out of their watersheds to urban centers.

Much of the citizenry as a whole has been excluded from the making of water policy. The key decisions have been made by large water organizations and their lawyers, engineers, and lobbyists. The field is widely perceived as too complex and forbidding for participation by ordinary citizens. Environmental groups, farmworkers organizations, and advocacy organizations representing poor people have provided a vital, though incomplete, remedy for this continuing problem of under-representation.

\section{General Principles}

- Water quality problems can best be managed on a watershed basis.

- Real improvement of the quality of the nation's waters requires aggressive action to deal with polluted nunoff.

- Water quality protection includes and depends on protection and restoration of aquatic ecosystems.

- Pollution should be prevented at its source.

- Effective water quality management requires actions based on the essential link between water quality and water quantity.

- Water quality protection programs should emphasize integrated resource planning and funding arrangements tied to the achievement of water quality goals.

\section{General Principles}

- The federal government should acknowledge and fulfill the special trust relationship with Indian tribes.

- Decisionmaking should include all affected interest groups.

- Decisionmaking bodies should provide the public with readily understood information and analysis.

- Where a transition from old to new values demands reallocation of water from existing uses, the equities of people with existing uses established under lawful prior policies should be respected. 


\section{General Principles}

- Institutional design for water resources management should be directed at making the most effective use of all levels of government, and strengthening opportunities and incentives for private action.

- Federal systems should be designed to promote integration of decisions and actions of government closest to the levels at which problems are posed and impacts felt.

- The federal government should promote integrated resource planning and management to meet water needs. "Integrated resource planning or management" attempts to find ways to meet water needs at the least cost - including economic costs and environmental and other costs and values, whether quantifiable or not - through consideration of all demand-reducing and supply-enhancing measures in a process that provides full opportunity for participation by members of the public.

- Federal agency organization for the implementation of federal water management policies should promote decisionmaking efficiency, consistent administration, and public understanding of how such federal responsibilities are exercised.

\section{INSTITUTIONAL REFORM}

To accomplish the goals of sound water policy, many water institutions must change. For some agencies, this means new approaches to carrying out their duties. In other cases new allocations and combinations of duties and functions are called for.

Governance of water policy is highly fragmented and, in some important respects, outdated. At the federal level, at least 23 subcommittees of Congress have some legislative or oversight authority over federal water programs. Lack of cohesion in policy-making is matched by fragmentation of administrative responsibilities across the executive branch. Many programs are unresponsive to contemporary societal needs and values.

In our federal system, states exercise considerable governmental responsibility over the use of water. State programs are fragmented in part by requirements of federal programs. Local governments and special purpose districts are major actors, but often confine their focus to the specific and immediate demands of a narrow constituency. The existing configuration of institutions is a major barrier to responsible and timely decision and action.

Reform should have as its ultimate objective the capacity to apply authority of all levels of government to the solution of water resource problems through participatory institutions at the "problemshed" level. Policy should then be developed through an open process that considers all quantifiable and nonquantifiable water values. 


\section{RECOMMENDATIONS}

Our recommendations include proposals for the first 100 days of the Clinton Administration and for the next four years. Some recommendations are general in nature; others arise more directly from the four national water policy objectives we have described. All call for reform in the way existing institutions govern water.

\section{FIRST 100 DAYS}

(1) The President should seek congressional approval of the Environmental Protection Agency (EPA) as a cabinetlevel agency.

\section{Water Use Efficiency and Conservation}

(2) The President should endorse market-based transfers of federally developed water, with adequate protection of the environment and of the economic vitality of communities from which the water is transferred.

(3) The Secretary of the Interior should assign a high priority to implementing Title 34 of Pub.L. 102-575, relating to the Central Valley Project, to effect the specific purposes of the Act and to set an example for managing other projects.

(4) The Administrator of the Environmental Protection Agency (EPA) should allow use of state wastewater treatment revolving funds for loans to utilities to assist in financing water conservation efforts, especially where long run costs can be reduced. Measures include meter installation, leak detection and repair, and retrofitting homes with water-efficiency fixtures in low-income neighborhoods, public housing, and depressed rural areas.

(5) The President should:

(a) Direct the EPA, the Army Corps of Engineers, and the Department of the Interior, in consultation with interested parties and with reference to the California Urban Water Conservation Agreement, to identify best management practices for urban water conservation, to be used as baseline measures for evaluating applications for federal permits (Sections 402 and 404 of the Clean Water Act) and federal agency Environmental Impact Statements;

(b) Direct the EPA, the Army Corps of Engineers, and the Department of the Interior to identify integrated resource planning procedures to be used by applicants for federal financial assistance for water supply or wastewater treatment; and

(c) Amend and strengthen the existing Executive Order on Energy Efficiency in Federal Facilities to assure that federal departments and agencies take prompt action to implement the requirements of the National Energy Policy Act relating to water and energy conservation in federally-owned buildings.

(6) The Secretary of the Interior should suspend all work on the proposed transfer of the Central Valley Project (CVP) to the State of Califomia until the Secretary, in consultation with the Office of Management and Budget and other experts and interests, promulgates rules that require recoupment of CVP federal construction, operation, and maintenance subsidies and ensure that all environmental obligations are met by any such CVP transfer. This rulemaking should be used in development of appropriate rules to govem other transfers of Departmental assets to non-federal entities.

(7) The Secretary of the Interior should begin aggressive implementation of Title XVI of Pub.L. 102-575 (Reclamation, Wastewater and Groundwater Studies), and should seek financial commitments from state and local governments as appropriate.

(8) The Secretaries of the Interior and Agriculture should direct that significant federal land transfers (i.e. exchanges, land disposals, sales) intended for residential and commercial development shall not be completed absent consultation with the relevant state and local governments concerning the adequacy of long-term water supplies to sustain the proposed development.

\section{Ecological Integrity and Restoration}

(9) The President should announce his strong support for reauthorization of the Endangered Species Act with provisions to promote ecosystem protection actions.

(a) The Secretary of the Interior should act expeditiously on listing threatened and endangered species and pursue timely development and implementation of ecosystem-based recovery plans, with particular emphasis on the Columbia and Snake River salmon.

(b) The Secretary of the Interior should develop a program for identifying ecosystems in distress on the public lands before it becomes necessary to list species as threatened or endangered.

(10) In support of the 25th anniversary of the National Wild and Scenic Rivers Act of 1968, the President should announce his support for a substantial expansion of the National Wild and Scenic River system during the next four years.

(11) The President should issue an Executive Order establishing a policy of watershed-level aquatic ecosystem protection and restoration. The order should direct the EPA and the Departments of the Interior, Agriculture, Defense, and Commerce (with oversight from the Council on Environmental Quality) to: review, revise, and coordinate their activities and operations to use all 
authorities under existing law to manage federal lands; to operate federally owned or licensed projects and facilities to protect and restore fish, wildlife, and their habitats on an equal basis with other primary project purposes (where such protection is not provided under the Endangered Species Act); and to use best management practices on federal public lands to achieve compliance with water quality standards (e.g. buffer zones; riparian area protection; limits on grazing, mining, and timber production). The Administration should support legislation to expand agency authority and revise project purposes where necessary.

(12) The President should:

(a) Withdraw the August, 1991 Wetlands Delineation Manual and appoint an interagency scientific task force (the EPA, U.S. Fish and Wildlife Service, Department of Agriculture, and Army Corps of Engineers) to revise the 1987-89 manuals to address regional variations and concerns utilizing the results of the forthcoming National Academy of Sciences report;

(b) Support funding for the Wetlands Reserve Program and other innovative agricultural programs that reverse wetlands loss or serve critical ecosystem needs; and

(c) Announce strong support for the Clean Water Act Section 404 (wetlands protection) permit program.

(13) The President should appoint Federal Energy Regulatory Commission (FERC) commissioners and power marketing administrators who are sensitive to ecological and non-power interests for hydropower licensing and marketing.

\section{Clean Water}

(14) The Administration should support annual investments of $\$ 2$ billion over the next four years to assist communities in complying with the Safe Drinking Water Act. Funding should focus on physical consolidation or upgrading of small systems unable to meet standards and the replacement of lead service lines and plumbing in low-income communities.

(15) The Administration should form a federal-state task force to identify, prioritize, and develop action plans for problem watersheds and pursue funding for those action plans under the nonpoint source program (Section 319 of the Clean Water Act) and the Farm Bill water quality provisions.

\section{Equity and Participation in Decisionmaking}

(16) The President should issue a formal statement recommitting the United States to protect Indian water rights and instruct the Attomey General to provide for the independent representation of tribes in water rights litigation and settlements.

(a) The Interior Department and the Office of Management and Budget should modify the criteria and procedures applicable to Indian water settlements to give primary recognition to the United States' special trust responsibility to Indian tribes and secondary consideration to the exposure of the United States to liability from litigation.

(b) The President should request Congress to: appropriate $\$ 250$ million to implement negotiated settlements; appropriate sufficient funds to assure the full and effective representation of tribes in water rights litigation; appropriate funding for tribal water management; and authorize a permanent Indian water rights settlement fund.

(c) The Secretary of the Interior should continue and expand the working group on Indian water rights settlements to facilitate Indian water rights negotiations.

(17) The Administration should initiate immediate rulemaking and other actions to ensure that federal programs are administered so as to avoid the creation of inequities and disproportionate effects on identifiable ethnic and low-income communities, and shall take steps to address issues such as:

(a) Fulfilling the needs of traditional Hispanic water management organizations;

(b) Preventing siting of waste facilities and sewage plants predominantly in low-income areas; and

(c) Modifying programs of the Soil Conservation Service (SCS) and other programs for water management and control in coastal Louisiana that result in denying access to local fishermen. 


\section{MID-TERM RECOMMENDATIONS}

(18) Within the first year of the Administration, the President should make a major, comprehensive address on water policy incorporating the recommendations of this report.

(19) The President should create a Water Task Force of federal, state, and tribal governments to develop a strategy for better coordination in the development and implementation of national water policy. The Task Force should study proposals for a new agency or other structures consolidating all federal water management functions and programs.

(20) Federal agencies with water program responsibilities should look for opportunities to delegate to or share management responsibilities and regulatory authority with governments at the level most closely affected by program decisions, including local, state, tribal, and regional governments. This should be conditioned upon compliance with federal standards. Authority for citizens to bring suit in federal court to compel compliance with federal standards should attend the transfer of regulatory authority.

(21) The Administration should appoint a broad-based group of federal, state, tribal, and citizen representatives to study the imposition of federal, state, or tribal fees for the diversion and use of water for hydropower, navigation, and other commercial purposes as a means of promoting more efficient use of this public resource and providing funds for water management and watershed restoration. The study should consider impacts on low-income families, exemptions for small water users, the retention of proceeds in the basin of origin, and the ability of market mechanisms and other existing institutions to achieve the same goals.

\section{Water Use Efficiency and Conservation}

(22) The Secretaries of the Interior and Defense should reevaluate existing or authorized Bureau of Reclamation and Army Corps of Engineers projects in light of contemporary needs and standards, including standards of water use efficiency, to identify opportunities for conjunctive use, water marketing, and the accomplishment of other federal goals, and should seek reauthorizations and deauthorizations as appropriate.

(23) The Secretary of the Interior should conduct an ongoing federal project contract review process triggered by requests for modifications, expirations, and other opportunities not covered by another established procedure such as for water transfers. Contracts should be renegotiated to reflect contemporary water needs, pricing for efficiency, and facilitating reallocation of project water.
(24) The Secretaries of the Interior and Defense should promulgate regulations to facilitate and encourage marketing of water from federal projects to promote efficient water uses to the extent consistent with the ecological integrity of affected streams and the economic vitality of communities in the area of origin.

(25) The Secretary of the Interior should utilize the pending Reclamation Reform Act rulemaking to modemize conservation practices at federal water projects and undertake aggressive enforcement of these conservation requirements.

(26) The Administrator of the EPA should develop incentives for water use efficiency and conservation. The EPA should:

(a) Make loans and grants, in coordination with the Soil Conservation Service (SCS), for demonstration programs to encourage agricultural water conservation as a means of addressing nonpoint source pollution; and

(b) Establish a clearinghouse for data and information regarding agricultural and municipal and industrial water conservation methods.

(27) Federal agencies investing in conservation should take full advantage of existing federal and state programs designed to protect conserved water as instream flows (such as the State of Washington's trust water rights program). In addition, the Administration should create incentives for states to adopt programs that dedicate a portion of conserved water to instream flow and other environmental purposes including groundwater protection. The Administration should provide incentives for contracting agencies and customers to improve efficiency in use and distribution of federal project water.

(28) The Secretary of the Interior, in the case of Reclamation projects, and the Administrator of the EPA, to the extent permitted by current law should encourage water pricing by urban water utilities promoting water conservation - e.g., eliminate declining block rates - provided that adequate safeguards are instituted to mitigate the impact on low-income families.

(29) The EPA, Health and Human Services Department (HHS), and Housing and Urban Development Department (HUD) should coordinate to provide opportunities for water conservation in low-income urban (public housing) and rural areas.

(30) Economics will dramatically limit the development of new water supplies. New projects should be planned and authorized by Congress only to meet the highest priority needs. The Administration should treat environmental quality as equivalent to regional 
economic development in applying the Principles and Guidelines. Modifications to existing projects should be considered by the appropriate agency and Congress only after the existing project has been reevaluated in light of new needs and water conservation objectives. Reallocation of existing supplies should be preferred as an altemative to new storage.

(31) The Secretaries of the Interior and Energy should review existing power contracts on a co-equal basis with water contracts. Federal hydropower pricing should reflect the full economic and environmental cost of producing power, and revenues should be used to assist in financing water conservation and ecosystem protection and restoration.

\section{Ecological Integrity and Restoration}

(32) The President should order the EPA, U.S. Fish and Wildlife Service (USFWS), and National Oceanic and Atmospheric Administration (NOAA) to prepare a report identifying critically important or representative ecosystems and specifying major ecosystem restoration opportunities in watersheds throughout the nation. Identified restoration actions should include a feasibility assessment containing prospective economic benefits and costs and appropriate incentive mechanisms.

(33) The Administration should establish a National Restoration Trust Fund in the United States Treasury to assist the USFWS and NOAA in efforts to protect and restore aquatic ecosystems. Initial funding should be derived from unspent income in the Land and Water Conservation Fund. Future revenues should be provided from federal water and hydropower surcharges, reductions in water-use subsidies, and establishment of broad-based user fees and assessments. Annual appropriations for ecosystem protection and restoration purposes should not be less than the annual income to the National Restoration Trust Fund.

(34) The new Administration, working through the Department of the Interior, EPA and U.S. Army Corps of Engineers, and in consultation with the states and tribes, should encourage and facilitate the formation of new watershed management organizations for the purpose of integrating water management at the "problemshed" level. A federal statute setting forth the essential elements of compacts to implement watershed management for interstate basins is advisable.

(35) Federal agencies should support nongovernmental and community-based approaches to the restoration of aquatic ecosystems, including watershed-based Community Restoration Trusts supported by the
National Restoration Trust.

(36) The Departments of the Interior and Agriculture should assert rights to instream flows for federal lands and encourage states to adopt and strengthen instream flow programs by using authority to grant or withhold federal funds and federal permit approvals.

(37) The Administration should support legislation that allows states and tribes to protect their most outstanding river segments against hydropower development.

(38) The Administration should seek to amend the Federal Flood Insurance Act to eliminate all subsidies for insurance premiums for new or post-storm reconstructed floodplain development, and to strengthen compliance with the Act.

(39) The EPA and Department of the Interior should establish comprehensive, publicly accessible, watershed-oriented monitoring programs, information bases, geographic information systems, computer models, and decision-support systems to assist public participation in developing water policy.

(40) Resource management agencies should be directed to establish quantifiable measures of ecological integrity which should then be incorporated into agency goals, objectives, and performance evaluation criteria.

(41) The Federal Energy Regulatory Commission (FERC) should condition hydropower licenses to include provisions requiring licensees to develop end use electric and water efficiency programs and to protect and restore watershed ecosystems, including restoring flows for fish and wildlife. FERC and the Administration should support the establishment of a dam decommissioning fund from license fees to cover the costs of dam removal or decommissioning.

(42) FERC licensing and relicensing should treat the ecological and nonpower values of rivers as co-equal with power generation and should ensure that licensees implement environmental and energy efficiency programs.

\section{Clean Water}

(43) The EPA should work with the states to develop models by which water quality and quantity concerns will be addressed in an integrated fashion.

(44) The Administration should support and work with Congress to reauthorize and strengthen the Clean Water Act to:

(a) Require enforceable polluted runoff controls for agriculture, timber harvesting and mining in noncompliance areas. 
(b) Strengthen pollution prevention measures in industrial, agricultural, and municipal sectors.

(c) Subject discharges from large dams creating water quality problems to NPDES permit requirements.

(d) Strengthen pretreatment programs to ensure that, where appropriate (e.g. for toxics), industrial discharges to municipal treatment systems are subject to the same requirements as other point source discharges.

(e) Keep clean water clean by protecting and restoring instream flows and other aquatic ecosystems, encouraging integrated watershed planning and management, promoting water conservation, and protecting pristine waters. To help achieve that goal, develop a clear statutory anti-degradation policy.

(f) Require the EPA to develop quantitative standards presently lacking for such parameters as nutrients, sediments, and salinity. Make compliance with water quality standards for entities not covered by water quality permits or other mandatory programs subject to the citizen suit provision, and provide for public involvement in the EPA's review of state water quality plans.

(g) Establish a Clean Water Fund with an annual authorization of $\$ 5$ billion which would be available to states on a cost-sharing basis to use on programs of their choosing designed to bring noncomplying waters into compliance with water quality standards. This funding would be tied to a requirement to develop integrated resource plans. States would have the flexibility to meet a broad range of infrastructure needs, including combined sewer overflow improvements, and to pursue water efficiency, aquatic system restoration, and other measures to control point and nonpoint source pollution. Failure to attain milestones in a plan could result in cutoff of funding and mandatory controls.

(h) Establish a national discharge fee program to pay all the costs of monitoring and enforcement.

(i) Establish a pollution prevention program that would make available an extra $10 \%$ investment tax credit to industries that can demonstrate investments in technologies that avoid discharges of toxic or other pollutants.

(j) Encourage the EPA under Section 303(d) of the Clean Water Act to provide technical and financial support to establish demonstration nutrient pollutant trading programs on a watershed basis in conjunction with state and local govemments. The
EPA should seek an authorization of $\$ 50$ million annually for these programs, with the goal of demonstrating cost effectiveness and the efficacy of their monitoring and enforcement.

(k) Establish integrated resource planning procedures for applicants for financial assistance.

(1) Establish basic water conservation requirements for Clean Water Act permits to help extend water supply or wastewater treatment capacity.

(m) Protect the food chain from toxic contamination by sunsetting the most dangerous toxic chemicals and by prohibiting the use of dilution as a substitute for toxic pollution abatement.

(n) Strengthen Section 404 to provide greater protection for wetlands.

(o) End the agricultural exemption from the National Pollutant Discharge Elimination System (NPDES) permit program in noncompliance areas.

(p) Provide financial and technical incentives to states to develop and implement comprehensive groundwater protection programs (including the protection of all freshwater groundwater as a drinking water source) with the EPA assuming jurisdiction when the state fails to implement an adequate program.

Equity and Participation in Decisionmaking

(45) The Administration should establish broad-based, local citizen advisory committees organized around federal water projects to advise federal project operators. The advisory committees should be provided with complete and useful information on all aspects of the projects' operations.

(46) The President should appoint an interagency task force, and support legislation to support locally-based urban and rural stream restoration programs in order to achieve the community, economic, recreational, environmental, and aesthetic benefits that these projects can provide.

(47) The President should convene summit meetings among interests in the Colorado River basin and the Missouri River basin, including state governments, Indian tribes, and citizen groups, to explore formation of basin organizations for including all affected interests in decisions required to meet the many diverse economic, environmental, and social demands on the rivers' limited resources. 


\section{Natural Resources Law Center University of Colorado School of Law Campus Box 401 Boulder, Colorado 80309-0401 (303) 492-1288 \\ FAX: (303) 492-1297}

